\title{
Accessible tourism and sustainability: a discussion and case study
}

Simon Darcya*, Bruce Cameronb and Shane Peggc

aSchool of Leisure, Sport \& Tourism, Faculty of Business, University of Technology, Sydney,

Australia; bEasy Access Australia, Kew, Australia; cSchool of Tourism, University of Queensland,

Brisbane, Australia

*Corresponding author. Email: simon.darcy@uts.edu.au

(Received 26 March 2009; final version received 14 December 2009)

\section{Published reference:}

Darcy, S., Cameron, B., \& Pegg, S. (2010). Accessible tourism and sustainability: a discussion and case study. Journal of Sustainable Tourism, 18(4), 515 - 537.

\begin{abstract}
This paper explores the concept of accessible tourism and its links with triple bottom line sustainability. Accessible tourism is reviewed through some of its central features including dimensions of access; universal design; and the nexus between ageing and disability. The triple-bottom-line (TBL) is then examined to better understand the financial, environmental and social considerations that arise from accessible tourism. The research design used in this explorative research incorporated a case study approach where a business case study instrument was developed. Methods included a review of management information systems, in-depth interviews with key informants, observation and participant observation. The study results revealed that rather than accessible tourism being a single construct, it forms one critical dimension of a series of interrelated, overlapping and interdependent business arrangements that extend beyond the business entity through a series of social networks within the destination region. It is argued that to properly satisfy the accessible tourism market, a more sophisticated understanding of accessible destination experiences is needed by tourism operators. The case study illustrates the considerable size and multi-niche markets served by accessible tourism destinations, the good fit between accessible tourism and TBL sustainable tourism, and the need for further research.
\end{abstract}

Key Words: accessible tourism, business case study, business case instrument, triple bottom line, universal design, ageing, disability.

\section{Introduction}

The nature of engagement with consumers and the expectations they have of the marketplace is rapidly changing (Victorino, Verma \& Wardlee, 2008). Yet, one market that has continued to be underserved by the global tourism industry is that of people with disabilities and those with access needs (Eichhorn \& Buhalis, 2007). On 24 July 2009 the President of the United States of America, Barack Obama, signed the United Nations' (UN) Convention on the Rights of People with Disabilities (United Nations, 2006, 2008). The United States became one of a range of signatory countries to a Convention which seeks to guarantee the rights of 
people with disabilities. Article 30 of the Convention asserts the right to access all areas of cultural life including that of tourism. It puts tourism operators formally on notice to change their operations in order to guarantee access to tourism goods and services for people with disabilities. Importantly, such human rights based initiatives have long been put forward as a significant social force for ensuring the citizenship (Hutchinson, 1997; Hutchison \& McGill, 1998; Meekosha \& Dowse, 1997) of people with disabilities generally and, more particularly, their purposeful engagement in cultural life (Darcy \& Taylor, 2009; Goodall, 2002; Miller \& Kirk, 2002). However, less well articulated is the underlying connection between human rights provisions and the social, environmental and financial considerations associated with sustainable tourism practice. This paper argues that research into sustainable tourism has so far largely ignored social arguments with respect to ageing and disability or those related to the underlying interrelationship between the social, environmental and financial considerations of accessible tourism. This paper seeks to articulate those relationships and connections. It puts the case for accessible tourism to be part of the social - and economic requirements of the triple bottom line accounting so central to the implementation of sustainable tourism.

The paper first examines the concepts that underlie accessible tourism including: disability; dimensions of access; and support needs. The components of universal design and triple bottom line sustainability are explored and shown to be central to the accessible tourism business case. A critical argument is developed that accessible tourism infrastructure, products and services can have a positive effect on business operations. Evidence is presented that greater accessibility not only makes good financial sense but it also has the potential to promote social and environmental objectives as well. Conceptually therefore, the authors argue a business case for accessible tourism grounded in the triple bottom line framework. 
This framework acknowledges the ever increasing emphasis on sustainability in the tourism industry, and the desire for businesses to grow and to succeed financially. It notes the significant growth potential in the accessible tourism market and its need to be premised on social justice and equity through human rights provisions.

\section{Disability, Dimensions of Access and Support Needs}

Government authorities throughout the world report that a substantial number of people have, or will likely acquire, disabilities over the coming decades (Australian Bureau of Statistics, (ABS) 2004; World Health Organisation, 2007). The level of disability throughout the world has increased over the last two decades to now average some $10 \%$ of the population. In most Western developed nations where there is an acceptance of community diversity, where average rates of disability vary from 15 to $20 \%$ of the population. A significant component of the changing disability profile is a direct consequence of the ageing of the population (Commonwealth of Australia, 2003; WHO, 2007). This component is particularly pronounced in Asian countries where the proportion of older adults is growing at a faster rate (Altman, 1975; World Health Organization, 2007). Figure 1 reveals the relationship between disability and ageing which presents a significant and ongoing challenge for global tourism (Dwyer, 2005); approximately 650 million people worldwide now have some form of disability, a number set to rise significantly over the next 40 years (World Health Organisation, 2007). This socio-demographic shift will impact every domestic and major inbound market, including those of the burgeoning Chinese and Indian markets. 


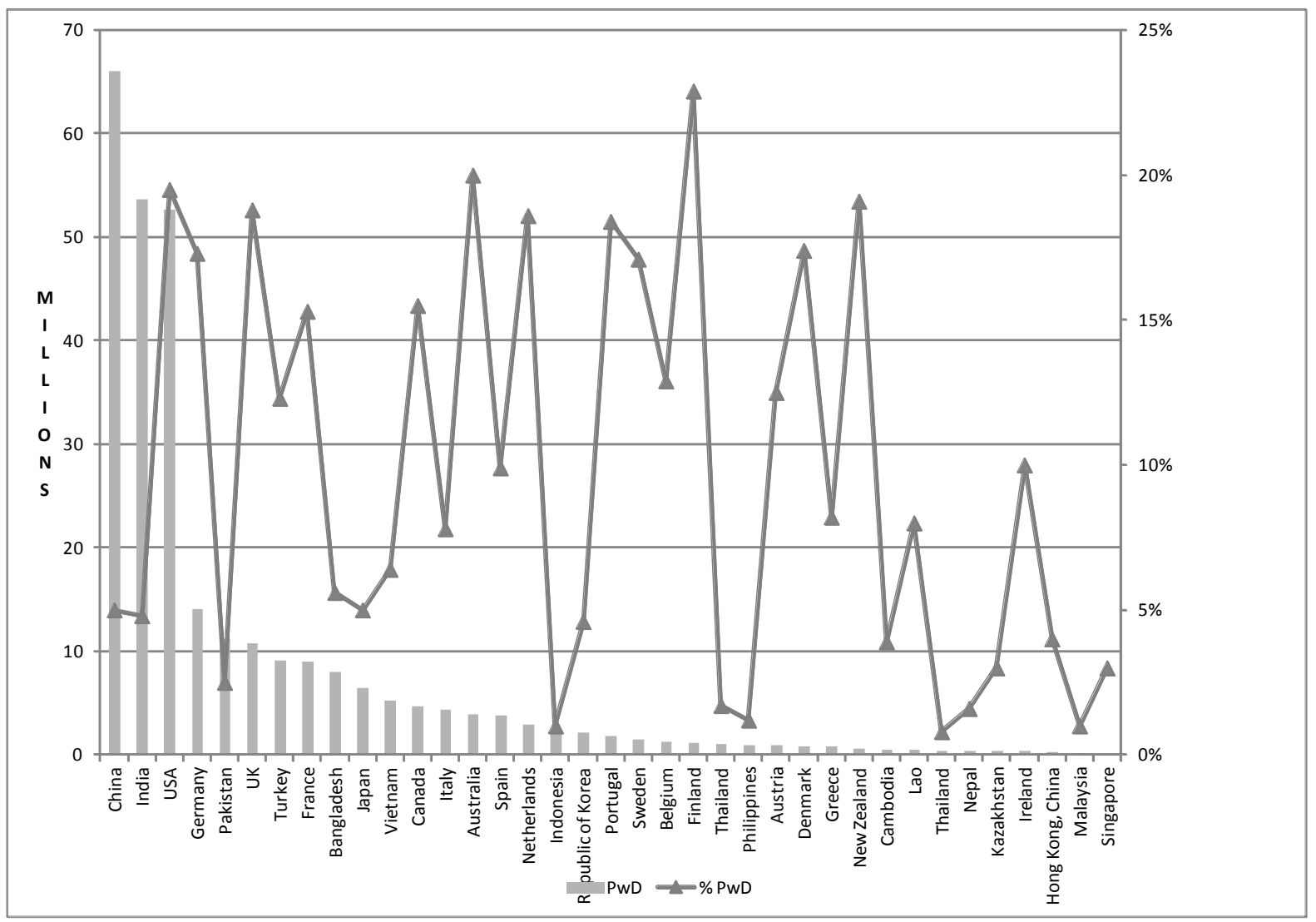

Figure 1. International population estimates of people with disabilities (Darcy \& Dickson, 2009,p. 36).

In much of Europe, the Americas and Australia, this change is now recognised and, through a combination of national human rights legislation, building codes and the disability rights movements, these regions are taking a more proactive approach to creating much more accessible infrastructure. Yet, for the most part, disability is still treated as a single dimensional construct. Much of the early research in this area found little differentiation between the dimensions of access, except for a few notable exceptions (Woodside \& Etzel, 1980; Murray \& Sproats, 1990; Darcy, 1998; Burnett and Bender-Baker, 2001). Disability is a multidimensional construct, with each dimension having its own access requirements that are significantly different to each other (Darcy, 1998; 2010). It is now recognized by most disability statistics that the multidimensional construct consists of:

- Mobility;

- Hearing;

- Vision; 
- Cognitive/learning;

- Mental health; and

- Sensitivities and long term health conditions (Disability Discrimination Act 1992).

The dimensions of access discussion provides a focus for enabling social participation through the provision of access requirements (e.g. ramps, tactile ground surface indicators, wayfinding signage etc.). The complexities associated with such a construct include recognising that, to facilitate citizenship, an individual with a multiple dimensions of access problem will require multiple levels of access provision. For example, a person with cerebral palsy may have a mobility dimension needing the use of a wheelchair or crutches, and a communication dimension through an associated speech impairment needing a communication board. Depending on their level of support needs, they may also travel with an attendant. Thus, this person requires an accessible physical environment, as well as assistive technologies and social policy inclusions. The complexity issue is, however, much more complex: this person's access requirements are likely to be very different to a person with arthritis, who may need a continuous pathway that includes handrails to assist in weight bearing, seats to provide resting areas, universal handles on doorways, and taps designed to assist reduced dexterity.

Apart from demonstrating the potential market size of the group, recent ABS data provides a sophisticated understanding of the market which Buhalis et al. (2005) diagrammatically detailed as a disability pyramid. Figure 2 serves to illustrate an adaptation of the disability pyramid concept, based on a scaled representation of the support needs identified in the ABS (2004) statistics. In practice, the shape may be viewed as more like a set of irregular building blocks than a 'pyramid', with each dimension of access as a 'pillar' supporting the efforts of 
citizenship. The pillars have been extended to specifically refer to the relationship between ageing, seniors and disability as well as understanding that some disabilities are invisible. Invisibility in this instance refers to those people who do not have any external signifiers of their disability. A person with learning disabilities cannot be identified visually, whereas a wheelchair user or a blind person with a guide dog can be visually identified as having a disability. And it should be noted at this point that while there is now a growing focus on the dimensions of access, a significant constraint identified across disability studies remains that of the attitudes of non-disabled people and, in the context of tourism, the industry's general lack of recognition of the rights and needs of people with disabilities (Daruwalla \& Darcy, 2005; Darcy \& Taylor, 2009).

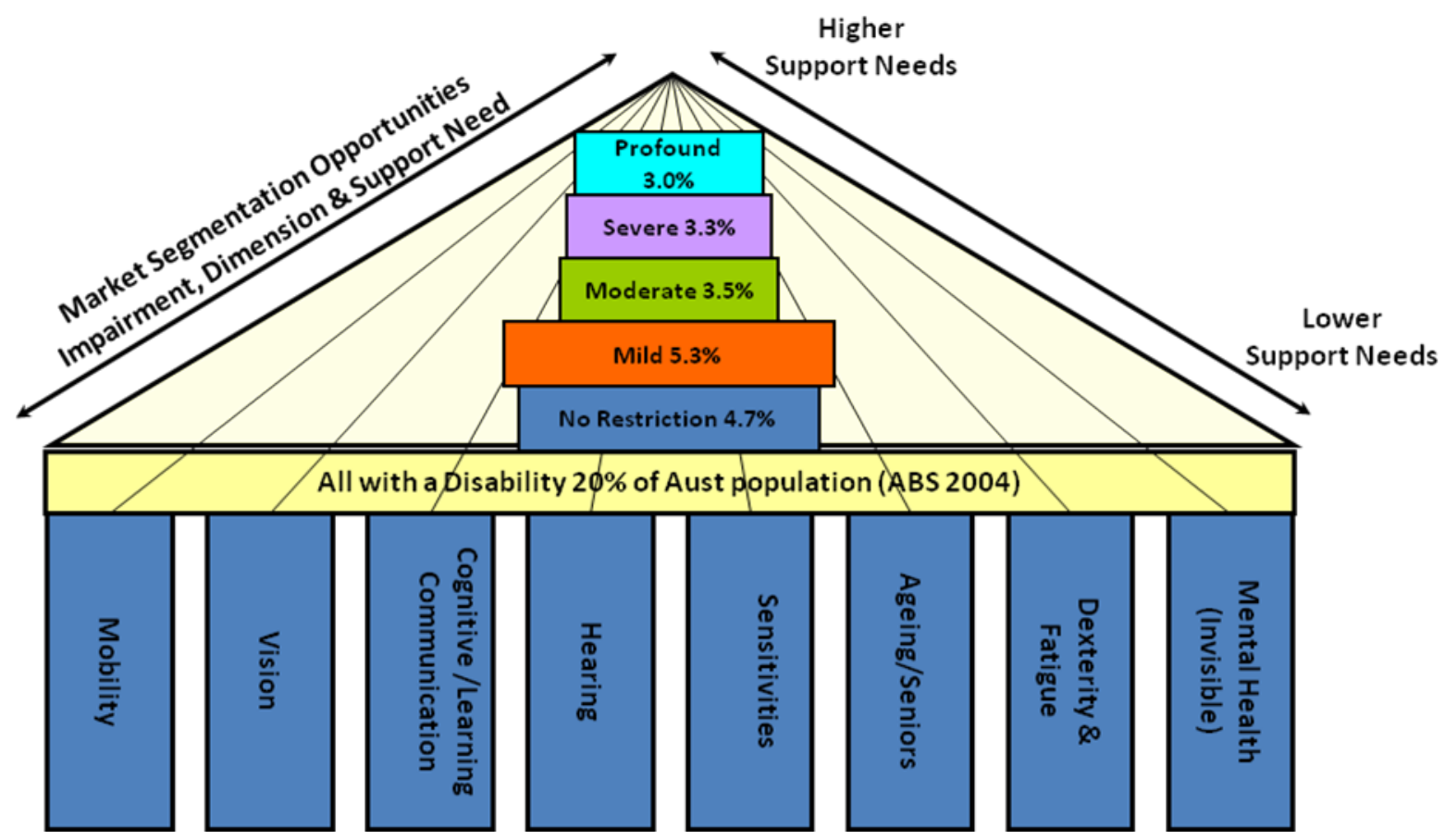

Figure 2. Dimensions of access by support needs.

\section{Perception Issues}

The design, planning and delivery of tourism services can benefit substantially from their alignment with the principles of universal design. That alignment would benefit many 
technically non-disabled people, including older adults, parents with prams and those tourism employees who need appropriate functional design for a broad range of occupational health and safety requirements (Preiser \& Ostroff, 2001). However, the industry seems unaware of the business and organisational benefits that might accrue from adoption of these principles. While many businesses meet their base legislative requirements, as exemplified by the provision of accessible parking and toilets, many do not consider the issue further (O'Neill \& Ali Knight, 2000). Few operators have made substantial connections between a high standard of access provision and other corporate performance indicators. In the accommodation sector for instance, many providers have yet to identify the benefits of accessible product provision; some even anecdotally state that 'rooms for the disabled' are a liability to their overall business. The accessible tourism market is perceived as low yield, with the stereotypical belief that people with disabilities and seniors have significantly less disposable income - a misconception (Australian Hotels Association, 1998; Darcy, 2000, 2002, 2003, 2008; Darcy \& Cameron, 2008; Healey, 2008; Pegg \& Stumbo, 2008).

\section{Accessible Tourism}

In the Australian context, accessible tourism has been formally recognized by the Commonwealth Department of Industry, Tourism and Resources (2003) with the release of Green and White Papers on national tourism policy in which people with disabilities and seniors were formally acknowledged as an emerging market. Since the release of these papers, Tourism Australia (2005) has established accessible tourism as a niche experience. However, there has not been any research, or industry strategy developed, to realise the opportunity that the access market offers. Furthermore, policy makers in Australia have not formally defined or conceptualised what accessible tourism is. Darcy \& Dickson, drawing on the work of the successful Olympic Coordination Authority's Access Guidelines for the Sydney 2000 Olympic and Paralympic Games, and incorporating a whole of life approach to 
disability, defined accessible tourism as:

Accessible tourism enables people with access requirements, including mobility, vision, hearing and cognitive dimensions of access, to function independently and with equity and dignity through the delivery of universally designed tourism products, services and environments. This definition is inclusive of all people including those travelling with children in prams, people with disabilities and seniors (2009, p34).

Yet, in many countries, the framework for developing accessible tourism or implementing universal design through disability discrimination law, building codes and accessibility standards does not exist (ESCAP, 2008). Without these requisite foundations in place to ensure access, and until disability is firmly on the agenda across all levels of government and the private sector, even the most effective advocates are likely to only achieve ad hoc outcomes rather than build a more strategically grounded approach to creating accessible tourism destinations. However, arguments for developing such approaches can be supported through greater effort from researchers and business operators to better understand the current nexus that exists between universal design and triple bottom line sustainability.

\section{Universal Design and Triple Bottom Line Sustainability}

Universal design has become a central concept in the development and understanding of accessible tourism. Universal Design is a paradigm that extends the concepts of continuous pathways, access and mobility, and barrier-free environments to incorporate intergenerational planning that recognises the nexus between ageing, disability and the continuum of ability of people over their lifespan (Aslaksen, Bergh, Bringa \& Heggem, 1997; Ostroff, 2001; Steinfeld \& Shea, 2001). Universal Design is defined as: 
the design of products and environments to be usable by all people, to the greatest extent possible, without the need for adaption or specialised design...The intent of the universal design concept is to simplify life for everyone by making products, communications, and the built environment more usable by more people at little or no extra cost. The universal design concept targets all people of all ages, sizes and abilities. (Center for Universal Design, n.d.)

Strategies that a tourism operator might use to better align themselves with the principles of universal design include:

- Incorporating a barrier-free design into the planning process

- Acquire knowledge of the appropriate laws and internationally recognised accessibility standards

- Include people with disabilities as planning team members

- Include an accessibility specialist on the planning team

- Exceed standards wherever possible

- Extend accessibility beyond the parking lot

- Incorporate accessibility into outdoor environments

- Plan for a continuous path of travel

- Consider aesthetics and environmental values when planning, and

- Ensure all materials used in the building process comply with suitable standards. (Moon, Hart, Komissar \& Freidlander, 1995)

Importantly, while Universal Design has a clear focus on environmental features its full application in the tourism industry has the potential to contribute significantly to a broad 
range of socially sustainable outcomes. Baron and Gauntlett (2002) noted that social sustainability occurs:

when the formal and informal processes, systems, structures and relationships actively support the capacity of current and future generations to create healthy and livable communities. Socially sustainable communities are equitable, diverse, connected, democratic and provide a good quality of life. (p. iv)

Accessible tourism extends beyond this concept by recognizing a 'whole of life approach' to tourism in which due consideration is given not only across the lifespan through the link between ageing and disability, but also through changing embodiments during lifespan (Darcy \& Dickson, 2009). Significantly, a 'whole of life approach' recognizes the inefficiency of enterprises that do not socially accommodate people across the lifespan. Thus, by developing products and services that are not inclusive of the whole community, the enterprise affects not only its own financial bottom line by effectively excluding part of the customer base but it is also socially inefficient by creating infrastructure that cannot be used by the whole community.

While this may be true of many businesses currently, the leisure and tourism industry has the greatest potential to contribute to social sustainability because its services can enhance the quality of life of individuals in many ways (Lloyd \& Auld, 2002; Rains, 2004). Ideally, such strategies are best developed at the conception of a tourism operation. Yet, this potential way forward is frequently ignored in spirit and/or in practice. The experiential aspects of accessible tourism are rarely articulated in the tourism planning process where different forms of embodiment need to be considered. As sustainable tourism has continued to gain 
mainstream acceptance, environmental reporting has become a core feature of many operations. However, while well intentioned when instigated, such a narrow approach has overshadowed reporting on social performance, which occurs only infrequently and inconsistently across a range of organisations and industries (Global Reporting Initiative, 2002).

Many tourism and hospitality businesses now seek to transform themselves into more efficient and effective operations. Issues relating to governance, long term sustainability and effective destination management are known critical factors for business success, yet they are addressed in a piece-meal fashion by the majority of operators. Most businesses change their service and product offerings only to achieve basic revenue driven targets, be they related to the concepts of total quality management, organisational change and restructuring (Kotter, 1998). Yet, Elkington (1997, p. 109) argued that 'if any business was to prosper over the long term, it must continuously meet society's needs for goods and services without destroying natural or social capital'.

Too few tourism operators have yet to give any real attention to the broader concept of the triple bottom line (TBL), to business activities that are considered socially, economically and environmentally sustainable or, as Gilkinson (1999, p. 2) described it, 'reporting that gives consideration to financial outcomes, environmental quality and social equity’. Dwyer (2005, pp. 79-80) found there had been little effort demonstrated by the tourism industry 'why individual businesses should consider their environmental and social performance rather than their financial bottom line, or indeed, the role that individual businesses can play in achieving sustainable tourism development'. Yet the tourism industry, in the Australian context at least, has become an important part of many regional communities as traditional industries have 
declined in recent decades. Tourism has become a key factor in terms of increased spending patterns in regional areas, and also because it supports community development, maintenance of transport, communications and training infrastructure (Commonwealth of Australia, 2003).

\section{Accessible Tourism Business Case Studies}

MacLagan (2003) contended that it is the mavericks of today's business world that are essential to championing the new directions that create an organisation's future. To simply not adapt to change, or do nothing, is realistically no longer an option for the vast majority of business entities. Holbeche (2006) added that unless organisations continue to adapt to changes in their environment, they are likely to enter a phase of strategic drift which is best characterised by lack of clarity, confusion and deterioration of performance. In this context therefore, case studies are valuable in that they concentrate on such mavericks who more often than not have a clear focus on elements of individualism, the power of reason, the value of argument and the base importance for managers and leaders alike of self-expression (Arnold, Heyne, \& Busser, 2005).

Kotter (1998) noted the most general lesson learnt from the more successful case studies is that the change process is a series of phases that, in total, requires a considerable length of time. Skipping key sequential steps in the process only serves to give the illusion of speed yet rarely provides the desired outcomes. A second, and equally important point argued by Kotter (1998, p. 3), is that making critical mistakes in any of the phases can have a devastating impact on operations, in that momentum for positive change can be slowed and hard-won gains negated. While not all ventures are successful of course, each individual case study can nevertheless provide valuable insights for others as to what works, and what doesn't. Importantly, they provide managers and owners of other operations with guiding points about 
what significant benefits can be derived by those operations that best align themselves with the broad notion of accessible tourism. Case studies are an invaluable aid for training and educating owners, managers and employees. This is particularly true in terms of awareness, attitude and/or technique training.

Case studies on accessible tourism are scant. They tend to come from government statutory authorities charged with recreation and tourism provision. An Australian government organisation, NICAN, (www.nican.com.au) has outlined best practice principles for recreation provision citing a number of successful accessible tourism businesses (Culyer, 1997). NICAN was part of a committee for the Office of National Tourism (1998), which produced fact sheets including 15 examples of tourism businesses providing high service standards for people with disabilities. They included five accommodation providers, three transport operators, three cultural/tourist attractions, two disability specialist tour operators, an interpretive trail, and a natural attraction. While purposeful, the commentary provided was however limited to the inclusive best practice identified.

More recently, the UK Department for Work and Pensions (2008) has made available case studies across the tourism, hospitality, retail, finance and legal areas. These case studies were, however, limited to a number of paragraphs identifying inclusive practice and some quotations from the business owners involved. The studies included four accommodation providers, two hotel/clubs, two outdoor recreation experiences, two farm stays and three attractions. They also included examples of their experiences of integrating employees with disabilities and tips for customers with disabilities for improving their service experiences. The UK examples provide a much more detailed account of the possible business outcomes that included: broadening the customer base, high occupancy of accessible accommodation, a 
loyal customer base, higher level of word-of-mouth recommendation, a self-financing investment, competitive advantage, contribution towards diversity profile, contribution towards winning a major tourism award, guarding against legal action and adding access to a new pool of potential employees. While the UK case studies have a higher level of detail than those by NICAN, there remained no clear information on the metrics from which to evaluate business operations across the triple bottom line framework. The lack of detail with respect to inclusive practices made them of limited value for potential business operators in terms of their planning processes.

This paper argues that the case study process should more adequately address the concepts of accessibility and inclusion to provide best practice exemplars encapsulating the notion of accessible tourism within the overall business plan of the operator. As Leiper et al (2008) noted, business cannot be truly regarded as tourism orientated unless it specifically targets tourists through its business planning and inter-business collaboration to leverage the best possible outcome from tourists. Similarly, little is known about how accessible tourism is best accommodated within an overall business operation.

\section{Research Objectives:}

The objectives of this research were to:

- $\quad$ Document triple bottom line outcomes of accessible tourism through a business based case-study of a successful operator;

- Identify the key indicators and collect data to measure the financial, social and environmental case; and

- Discuss the findings of the triple bottom line approach to better understand the complexities of accessible tourism provision. 


\section{Research Design: Developing the Case and Measuring TBL Business Performance}

Due to the lack of accessible tourism business case studies within academic and business research, an explorative mixed method interpretive design was used (Morse, 1991, p 121). This approach was employed using a selected case as the object for study through a triple bottom line scorecard. The research design sought to expand an understanding of business performance beyond simply that of financial measures. The study aimed not to generate theory, but to describe specific situations and thus better inform those involved in the planning, organization, conduct and management of businesses. These outcomes, as Dey (1993, p 6) argued, are both legitimate and worthwhile in the context of a mixed method, interpretive research design. The study was part of a larger research project that developed an overall case study methodology for understanding the considerations of accessible tourism (Darcy, Cameron, Pegg \& Packer 2008). The research design employed a three stage process: Delphi group; field work; data analysis.

\section{Stage One - Delphi.}

This stage used the collective expertise and experience of a Delphi group to determine critical components of the research to be undertaken. The business case study contexts were identified through a Delphi group of professionals with experience in accessible tourism development, a group first established in 2005 to develop a research agenda for accessible tourism in Australia (Darcy, 2006). It included individual business owners, members of state tourism organisations, government disability representatives, disability service providers, consultants and academics. They identified key considerations of accessible tourism enterprises and a range of high standard accessible products, across state borders, market segments and reflecting a range of ownership structures. For this paper, one of the earliest 
established accommodation businesses was chosen because it was identified by the expert panel as exemplifying essential elements of best practice. The Delphi contributed to the following three areas:

1. Generate a list of best-practice examples of accessible tourism for inclusion;

2. Decide the key measures to determine successful examples of the accessible tourism best-practice; and

3. Develop a Business Case Instrument (BCI) to reflect these key measures.

The first two issues are not discrete. Rather, they were considered interdependent and overlapping. Hence, the research involved a series of iterations including an e-mail survey of the Delphi group, individual interviews with the group and finally a focus group meeting (via teleconference).

\section{Stage Two - fieldwork.}

This second phase of the research served to operationalise the findings of the Delphi study. Participants were contacted by phone and e-mail and then provided with an information sheet outlining the study and the business case instrument. Once the participant had agreed to be involved, follow up phone calls and personal visits by research team members gathered the required information. Importantly, this stage was iterative, involving a series of continual reflections about the data. As such, a necessary component was the revisiting of the data collected via e-mail, phone calls and, in some instances, in-person visits by a member of the research team.

\section{Stage Three - data analysis and report writing.}

The research applied a common base-line methodology to the business. The research team 
was able to explore in some rigour the different approaches and methods utilised by the business operations. Post this activity, the team sought to identify key measures that reflected best business practice in accessible tourism. A series of Key Indicators was developed which it believed reflected good business practice and which, importantly, served to meet the core components that drive the Triple Bottom Line concept. Table 1 identifies the key indicators for:

- A financial report card,

- An environmental report card

- A social report card. 
Table 1. TBL key indictors.

\section{A. Financial Report Card}

An organisation's financial report card focuses on variations to budget, the cash position,

profitability, balance sheet structure and viability. The annual financial report reviews:

- Annual operating performance

- Cash management

- Debt management

- Short-term viability of the organisation

- Long-term viability of the organisation

\section{B. Environmental Report Card}

An organisation's environment report card considers the following:

- Recycling water and solid waste (paper, cardboard, plastics, etc.)

- Energy conservation

- Environmental conservation

\section{Social Report Card}

An organisation's social report card considers the following:

- Enablers, inclusive practices and diversity of experience

- Employee and guest/visitor safety

- Business's support of the community

- Community partnerships

The research team's sources included notes from the interviews, copies of documents and archival material sourced for the study. Tabular material was then generated. A matrix of categories or themes, placing the evidence collected within them, including flowcharts and frequency tables, facilitated analysis and interpretation involving continual reflection about the data. At the outset eleven businesses providing accessible tourism services were identified and contacted, from which five agreed to full participation. In the context of this study, TBL was operationalised as a reporting device and as a strategic approach to business decisionmaking. It employs reporting tools to understand the economic, environmental and social implications of decisions for organisational activities (Gilkinson, 1999; Savitz \& Weber, 2006). More often than not, TBL reporting has tended to be based around a quantitative summary that covers business performance across the three main components over the previous year (Storer \& Frost, 2002).

\section{Data Collection Methods}

A major focus of the study was the ongoing development of a triple bottom line business case 
template for accessible tourism. This involved an ongoing iteration between the literature, the data being gathered, the business owner and the researchers, based on an understanding that accessibility has four broad dimensions - mobility, vision, hearing and cognitive. The case studies needed to incorporate any of the dimensions that were appropriate to the business. The business did not have to provide all four dimensions of access but did need to provide access related to one of these dimensions. Until now, much accessible tourism research has focused on people with mobility needs. However, there has been recent research into the tourism experiences of people with vision impairments (Packer, Small, \& Darcy, 2008), into people who are deaf or hearing impaired (Deafness Forum \& HMAA, 2005) and much can be learnt from the work of the recreation sector with people with cognitive disabilities. The team drew together existing sources of information about access, best-practice examples of formulating products, and evidence about how to meet the accessibility market's needs, and applied this to developing the report cards and refining the business case instrument.

While data was collected from archival and management information sources, the principal means of data collection for was by way of semi-structured face-to-face interviews. This versatile and flexible method is essentially a two-way conversation between an interviewer and a respondent (Mason, 2002; Zikmund, 2003). Interviews can adopt diverse characteristics, from telephone interviewing, to personal or group interviewing (Henderson \& Bialeschki, 2002). The interview structure can be modified to suit specific needs, from highly formalised and structured procedures, using standardised questions for each respondent, to informal and unstructured conversations (Patton, 2002). The general goals of interviewing are to create a positive atmosphere, obtain an adequate response, ask the questions properly, record the response and, wherever possible, seek to minimise or avoid outright biases (Balvanes \& Caputi, 2001). 
“The standardised open-ended interview consists of a set of questions carefully worded and arranged with the intention of taking each respondent through the same sequence and asking each respondent the same questions with essentially the same words” (Patton, 2002, p 342). Henderson and Bialeschki (2002) recognised three benefits in undertaking this approach during the data collection phase. These relate to the methodology instrument being available for inspection before and during the process and that variations amongst respondents are minimised, ensuring greater consistency throughout the interview process. It is also worth noting that since the questions are planned ahead, there is also the added benefit of optimisation of interviewee time. The aim "is to offer each subject approximately the same stimulus so that responses to the questions, ideally, may be comparable” (Berg, 1989, p 15).

\section{Other Data Sources Utilised}

Supplementary information included:

- Management Information Systems e.g. internal reports, online material, brochures, external studies/evaluations;

- Audio-visual material;

- Archival records e.g. archived websites, organisational records detailing service provision;

- Observation and participant observation at the business.

\section{Access audit/Management Information Systems}

Access audits were undertaken using accredited access auditors through the ACAA (www.access.asn.au) and directed by a combination of generic and specific contemporary best practice (Cameron, 2000; City of Melbourne, 2006; Villamanta Publishing, 1997), 
Disability Action Plans and relevant official documents of individual organisations were reviewed so as to not replicate previous work and provide a realistic time frame.

\section{Semi-structured interviews with business owners and workers}

The interviews elicited the interviewee's ideas and opinions regarding issues, innovations, constraints, enablers and possible solutions to accessibility in their establishments. This provided in-depth knowledge of how key providers manage accessibility within their precincts.

\section{Observation of the business}

This involved both participant observation and unobtrusive observation of the establishments access features, overall product and in some cases, services provided. Such activity was undertaken by a member of the research team using a protocol established by the group to ensure consistency of approach and data collection methods.

\section{Data Analysis}

The information gathered as outlined above provided the "chain of evidence" that links the research questions, the data collected and conclusions drawn (Yin, 2003, p 105). In analysing this data it was necessary, as Miles and Huberman (cited in Yin, 2003, pp 110-111) suggested, to create a matrix of categories or themes, placing the evidence collected within them, and developing, as appropriate, flowcharts, tables and frequency tables. Table 2 provides a snapshot of the tabular approach identifying key milestones in O’Carrollyns' development, (see below) and main elements comprising the TBL components. Each of the Report Cards is examined in the following sections. 
Table 2. Snapshot of TBL indicators for O'Carrollyns.

1 Commencement of Triple Bottom Line Activities

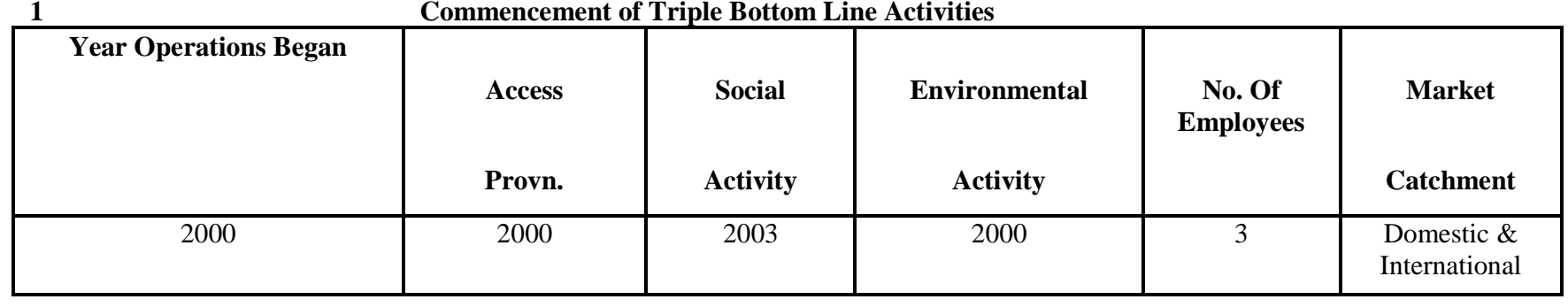

\begin{tabular}{|c|c|c|c|}
\hline \multicolumn{5}{|c|}{ Financial Report Card } \\
\hline Finances & Debt \% & Occupancy & Activity \\
\hline Prepared to provide & Not Avail. & Provided & Provided \\
\hline
\end{tabular}

\begin{tabular}{|c|c|c|c|}
\hline Recycling & $\begin{array}{c}\text { Energy } \\
\text { Conservation }\end{array}$ & $\begin{array}{c}\text { Limit } \\
\text { Greenhouse }\end{array}$ & $\begin{array}{c}\text { Environmental } \\
\text { improvements }\end{array}$ \\
\hline $\begin{array}{c}\text { Attempt to recycle water \& } \\
\text { solids }\end{array}$ & $\begin{array}{c}\text { Unit design, } \\
\text { insulation }\end{array}$ & $\begin{array}{c}\text { Limit washing } \\
\text { machine use }\end{array}$ & $\begin{array}{c}\text { Five star energy rating } \\
\text { design. } \\
\text { Composts }\end{array}$ \\
& $\begin{array}{c}\text { Limit water } \\
\text { usage }\end{array}$ & Bush fire protected. \\
\hline
\end{tabular}

\begin{tabular}{|c|c|c|c|}
\hline 4 & Social Report Car & & \\
\hline Inclusive Enablers & Safety & $\begin{array}{c}\text { Unexpected } \\
\text { Outcomes }\end{array}$ & $\begin{array}{c}\text { Community } \\
\text { Support/partnerships }\end{array}$ \\
\hline $\begin{array}{l}\text { Units, equipment, vehicle, pool, } \\
\text { pathways }\end{array}$ & $\begin{array}{l}\text { OH\&S audit and } \\
\text { emergency plans }\end{array}$ & $\begin{array}{l}\text { Family/small } \\
\text { child friendly }\end{array}$ & $\begin{array}{c}\text { Access committee } \\
\text { Koala Foundation } \\
\text { Local operators, } \\
\text { Tamboi Queen }\end{array}$ \\
\hline
\end{tabular}

b 
It should also be noted that the process of analysis and interpretation involved "continual reflection about the data, the asking of analytic questions and the writing of memos" (Creswell, 2003, p 190). The use of what Spiro (cited in Stake, 1994, p 242) called "crisscrossed reflection” between data sources was a feature of the analysis undertaken (Harris 2006). Lastly, the research was approved by UTS HREC: Urban Tourism Program Ethics Approval, clearance number 2006-165P.

\section{Case Study Findings: O'Carrollyns}

O’Carrollyns is situated at One Mile Beach, Port Stephens, $160 \mathrm{~km}$ north-east of Sydney, Australia. Its premises were universally designed to provide accessible accommodation for all travellers. Its leadership on this aspect of service provision has prompted other tourist businesses in the area to expand and develop access to their own accommodation and activities. The business began in October 2000 with six holiday bungalows on a five acre property, overlooking a billabong in a bush setting. It has grown to encompass nine cabins comprising car parking, accessible paths of travel to level entries, open plan living area including kitchen with access to bench and sink, reachable facilities, lever taps, internal sliding doors, open plan accessible bathroom with lever taps, roll-in shower, hand held shower rose and grab rails for the shower and toilet. Shower chairs, commode chairs, hoists, hospital beds, monkey bars and bed sticks are also available. An accessible path of travel is provided around the facility with graded concrete pathways leading to the lake, bridge, lookout, and fishing spot. An accessible performance stage is adjacent to an undercover barbecue area with conference/meeting room that has accessible bathroom facilities. There is a heated swim and spa pool, equipped with a hoist. In addition to the accommodation offered, 
O’Carrollyns provides accessible holiday experiences with a 4WD vehicle and beachwheelchair access, while local fauna such as koalas and echidnas roam the site.

A number of illustrations and diagrams can be found on the web based version of this paper.

\section{Financial Report Card}

To maintain confidentiality, detailed financial data was only provided in respect to occupancy and market segment sources. It is presented in Table 3 and Figure 4.

Table 3. O'Carrollyns occupancy accommodation.

\begin{tabular}{|c|c|c|c|}
\hline Financial Year & General & Access & Total \\
\hline $2000 / 01$ & $15 \%$ & $1 \%$ & $16 \%$ \\
\hline 2001/02 & $40 \%$ & $4 \%$ & $44 \%$ \\
\hline $2002 / 03$ & $43 \%$ & $13 \%$ & $56 \%$ \\
\hline $2003 / 04$ & $48 \%$ & $13 \%$ & $61 \%$ \\
\hline $2004 / 05$ & $34 \%$ & $19 \%$ & $56 \%$ \\
\hline 2005/06 & $35 \%$ & $17 \%$ & $52 \%$ \\
\hline 2006/07* & $32 \%$ & $18 \%$ & $50 \%$ \\
\hline
\end{tabular}

*10 months

Table 4. Source of O’Carrollyns markets.

\begin{tabular}{|c|c|c|c|}
\hline Market Segmentation, Occupancy by Year & $2004 \backslash 05$ & $2005 \backslash 06$ & $2006 \backslash 07$ \\
\hline Families & $13 \%$ & $16 \%$ & $20 \%$ \\
\hline Couples & $19 \%$ & $15 \%$ & $14 \%$ \\
\hline Groups of Friends/Extended Family Groups & $23 \%$ & $21 \%$ & $9 \%$ \\
\hline Conference/business/recreational Groups & $7 \%$ & $2 \%$ & $11 \%$ \\
\hline Overseas Visitors/Back packers & $7 \%$ & $6 \%$ & $11 \%$ \\
\hline Respite Groups & $6 \%$ & $10 \%$ & $22 \%$ \\
\hline Retirement Villages/Nursing Homes & $7 \%$ & $7 \%$ & $3 \%$ \\
\hline People Requiring Barrier Free Holiday & $18 \%$ & $23 \%$ & $10 \%$ \\
\hline
\end{tabular}




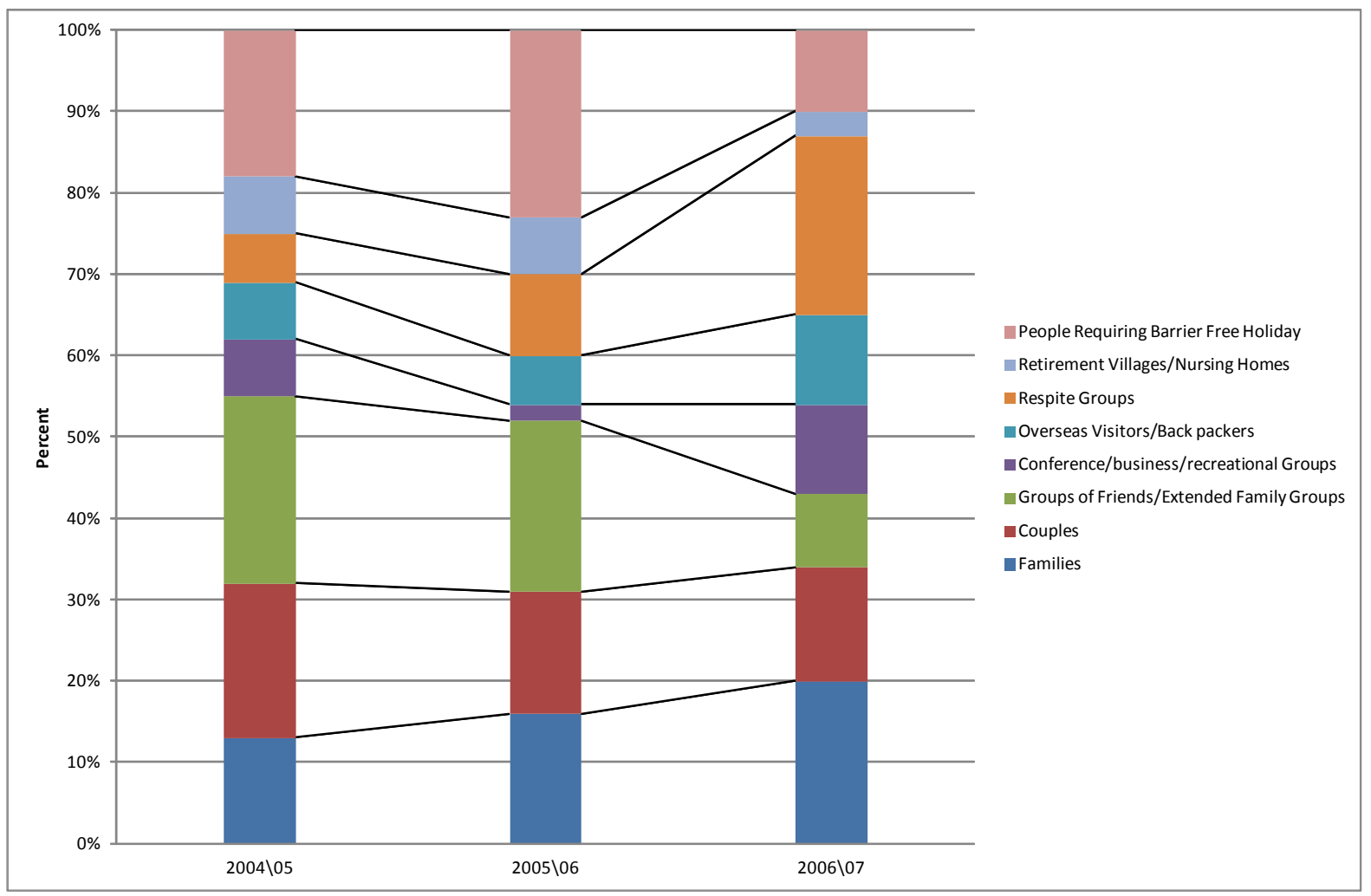

Figure 4. Sources of O’Carrollyns markets.

Since opening in 2000, overall occupancy has increased to 61\% in 2003-4. Occupancy requiring access peaked at $19 \%$ in 2004-5. Occupancies subsequently decreased reflecting a $50 \%$ increase in cabins from 6 to 9 . However, access occupancies reached $18 \%$ in the ten months of 2006-7. The resort's development demonstrated that (a) a market for access existed and (b) the size of the market that the provision of access generates, i.e. the multiplier effect. The owner operator noted:

I didn't realise the market was that big...It's the number of people in wheelchairs or who need access but it's the hangers on, the people that come with them. To have the place booked because one person is in a chair I think is remarkable. But that person has brought another 40 guests with them. 
This supports previous research that suggested the market dynamics of accessible tourism are not fully understood by the industry. As a group of family or friends, research suggests that people with disabilities travel with an average of between 3-5 people in their group for day trips or overnight trips based on US, UK, Canadian and Australian studies (HarrisInteractive, 2002, 2005; Keroul, 2001; Darcy et al., 2008; English Tourist Council, 2001).

The data contained in Table 4 and Figure 4, shows for the 2006-7 year, guests specifically seeking access represented 9\% of bed nights (People Requiring Barrier Free Holiday) but a further $25 \%$ of occupancy relates to other market segments needing a high degree of access (Respite Groups 22\% and visitors from Retirement Villages/Nursing Homes 3\%).

\section{Environmental Report Card}

Responses to environmental issues fall into predominantly two categories, (1) resort initiatives, and (2) guest initiatives. As outlined in Table 2, the resort has implemented a series of environmental and efficiency initiatives. The resort abuts a Koala conservation zone and has fully integrated its vegetation planting to capitalise on this feature, including planting native paper bark trees. 'Wild' koalas and wallabies visit regularly. The resort implements strategies to achieve improved recycling and waste disposal and provides for recycling with appropriately located bins etc. However, the manager acknowledges the problem that:

people on holidays don't care; they just throw all their garbage in the recycle bin, they don't care. Over $60 \%$ of people do that. In particular overseas people don’t even know. So recycling can become a waste of time. I still do it, but it is difficult. 
The cabins were designed and constructed to achieve a five star energy rating, with insulated walls, roofing and strategically placed windows to facilitate cross ventilation. Guests are encouraged to minimise their washing. Drying is undertaken outdoors and undercover. Regenerating the undergrowth and mulching to keep the worm action in the ground because "that makes the trees grow quicker" is another initiative.

Importantly, O’Carrollyns, while designed from the outset to conform to the Australian Standard for Access and Mobility (AS1428), was also planned with consideration that the resort is sited in a bushfire prone area. Therefore, construction reflected the anticipated safety requirements, for example, colour-bond walls and no guttering, so that leaf litter does not accumulate and become a fire hazard and rain water runs directly off the roof to replenish the water aquifer, the principle source of O’Carrollyns water supply:

You need a licence to draw water out of the ground but we have a big pipe from the permanent dam on the property and it was put there to catch the rain water. The rain water runs off the rooves of the units and filters back into the aquifer. So the water we drink comes out of the aquifer and we're putting water back into the aquifer.

As result lower cost insurance premiums have been obtained.

The resort draws on the principles of universal design to improve the functionality of the space for people with different dimensions of access needs. The provision of 'continuous pathway' (Standards Australia 2001) to all areas of the resort provides a binding element to pedestrian movement. It also allows an 'electric golf buggy' to service all cabins for delivery 
of luggage, cleaning and any other maintenance required, and universal design features also resulted in a series of social outcomes.

\section{Social Report Card}

Easy access for everyone was designed into the resort and diversity of experience is facilitated by a can-do attitude amongst the staff. Evidence of this in practice includes a ramp for guests to access a 4WD vehicle to experience tours to the beach, provision of specialised beach chairs so guests can sit on the sand and socialise or experience the power of the waves in the ocean. Further evidence is the positive influence on other local tourism operators, including better accessibility for visitors participating in a dolphin watching cruises onboard the charter boat, Tamboi Queen. The resort operators also conducted an occupational health and safety audit for the site with specific recommendations implemented with respect to accessibility for attendants and carers. Subsequently, the resort operators formalised a risk management plan and ensured all cabins were fitted out with emergency plans as well as audible fire alarms. The cabins themselves have been designed with roll-in showers and extra circulation space throughout, which has seen unexpected usage by parents who can easily fit a cot with their baby next to their bed.

The business itself also supports other businesses within the region that offer good access. O’Carrollyns now has a working relationship with a diverse range of local entities including Tamboi Queen Cruises, Nelson Bay Taxis, Port Stephens Coaches and the management of the marina. Local community relationships have been also developed with the Koala Foundation, Access Committee, Probus Clubs, fishermen's co-operative, car clubs, and other special interest groups. The relationship with the local Koala Foundation (KF) has developed to an unexpected level. O’Carrollyns involves its guests by having them contribute to the KF 
by donation rather than charging for a service, such as fishing for Australian Bass, which are stocked in the dam on the resort property. The KF uses the establishment as a benchmark because of the way it works, including having the specific tree species on site for the Koalas. O’Carrollyns has demonstrated that suitably placed and considered tourism developments and the natural environment can comfortably co-exist where effort is made to ensure the facility and its visitors are respectful of the natural setting.

We put pipes and old logs around the place so lizards and echidnas use them as homes. There are a lot of koalas that are breeding and coming on to the property. The undergrowth is growing back beautifully and in some areas we're starting to see the little finches. Birdwatchers love it. .....many people get enjoyment out of critters, especially kids, so I’ve encouraged critters by putting water everywhere....(guests pay) \$5 each into the koala can (to help koalas), to fish for Bass off the bridge. They hadn't fished before and had a marvellous time. The Herons that sit in the trees and look at the fish must think it's great.

Lastly, O’Carrolyns website provides comprehensive detail of its access features, universal design inclusions and community networks. Rather hiding these features, they are prominently located on the front page of the website. The detail provided assists individuals make an informed and important decision on whether the access provisions meet their needs. (Eichhorn, Miller, Michopoulou \& Buhalis, 2008; Darcy \& Cameron, 2008).

\section{Discussion}

A significant issue within the financial report card was the reluctance of business to provide financial data to the researchers. Trust is clearly an important issue. In the case of 
O’Carrollyns, there was particular concern raised by management about possible undesired attention being brought to the business.

To understand the financial position of the organisation and the relative position of accessible tourism within that context a series of measures was requested. Information was sought on financial movements between accounting periods or proportional to a base. Indicators requested included: Growth in Revenue as a percentage, Growth in Net Profit before Tax (NIBT) as a percentage etc. All of the measures are contained in the business case instrument along with definitions. As Table 3 revealed, a substantial and significant growth in guests seeking access was recorded over the years since the operation commenced.

The Environmental Report Card (ERC) was a series of indicators identified as reflecting organisational performance in respect to the environment. The ERC focuses on components such as waste water quality and recycling, recycled solid waste, weed and pest control, greenhouse gas emission reduction, reclamation and conservation projects: all reflect the enterprises' impact on the environment. O’Carrollyns had developed policies, strategies and implemented actions to recycle materials relevant to their area of operation. A significant amount of time and effort was also put into restoring and improving the surrounding environment. The drivers behind this, based on comments during the interviews, suggest a desire to meet the aspirations of guests for a natural protected environment, often specifically involving the sighting of native fauna; a visitor sentiment echoed in the wider tourism and environment literature (Newsome, Moore, \& Dowling, 2002; Okello, 2005; Worboys, Lockwood, \& De Lacy, 2005). 
The Social Report Card (SRC) is a series of indicators that are identified as reflecting organisational performance in respect to social sustainability (Barron \& Gauntlett, 2002). The SRC focuses on components such as inclusive access practices, employee safety, workplace stability, community support, involving the community, community works and partnerships all reflecting the enterprises' impact on society and local community. O’Carrollyns provided access provisions to all areas of their facilities based on universal design principles (Ostroff, 2001). Safety was accorded a high priority for staff and guests where they implemented the following: $\mathrm{OH} \& \mathrm{~S}$ audits and training, emergency plans, written safety instructions, signage, security lighting, security patrols and the provision of equipment to ensure the safety of employees.

Over time, there is clear evidence that the owner operators of O'Carrollyns have formed relationships with commercial operators, not-for-profit groups and other organisations in and around the Port Stephens area and that these relationships have been of great value to the operation. In particular, these relationships contributed towards better destination experiences for customers, increased customer loyalty, repeat visitation and positive word-of-mouth bookings. In particular, relationships with disability organisations and access committees provided a strategic approach to reaching large numbers of people with disabilities, and the accessible tourism market more generally. In this aspect, the concept of social sustainability was operationalised through community based entrepreneurship (Johannisson 1990; Johannisson \& Nilsson 1989). The management at O’Carrollyns has effectively placed their product within the regional development framework of Port Stephens through community interaction across the commercial, government and not-for-profit sectors. What becomes evident is that the niche operator's success is driven by the desire to 'act locally but think globally' through working together to facilitate regional tourism development (Dredge \& 
Jenkins 2003; Lyons 2001).

In reviewing the various elements of the study, a number of positive outcomes were generated. The first was the development of a business case instrument set within the TBL framework. The use of in-depth interviews and field visits to collect data and develop the instrument rather than a questionnaire style completion illustrated the potential benefits of qualitative methods in this process (Morse, 1991, p 121). Data collected from O’Carrollyns, and from the other business case studies that formed part of a wider study, illustrate that considerations of social and environmental factors do lead to improved financial returns (Gilkinson, 1999). Study results also demonstrate that a viable accessible tourism market exists. Nevertheless, tapping the potential of this market requires a commitment to the provision of quality accessible experiences and inclusive practices that go beyond the basic access requirements such as those set out by the Australian Standards for Access and Mobility. Furthermore, O’Carrollyns has developed such a sound working relationships with the local community with respect to access provision that they have now become not only an example of best practice but also a source of advice and assistance for community and regional organisations with like intent.

The case study reported in this paper indicates that the accessible market is drawn from both domestic and international tourists. It also revealed that families were an important segment of the accessible market where one member of the family or group had a disability and that families or groups comprising a member with a disability, enjoyed the benefits of an accessible environment. There is significant disability group travel potential, identified through a number of the businesses that provided tourism opportunities during shoulder and mid week periods. Accessible premises were also patronised by elderly guests and families 
with small children.

The importance of environmental responsibility and the conservation of surrounding bush land, where applicable, highlighted the potential economic benefits that flow from these sorts of actions. It also suggests that lessons can be learnt from the environmental sector in terms of how best to communicate messages to consumers, particularly as they relate to guest behaviour toward recycling, bush regeneration and endangered species protection.

\section{Conclusion}

Businesses providing a quality accessible experience demonstrate there is a market in accessible tourism and that market adds to activity/occupancy rates. The accessible tourism business provided about 20 percent of the overall financial position of the operation. Without this important component of the business O’Carrollyns would have been far less prosperous position. O’Carrollyns developed inclusive practices that went beyond the basic access requirements and were surprised to learn that other groups with accessibility needs were quick to patronise the accessible features, particularly those related to accommodation provision.

The use of business cases to promote the benefits of accessible tourism is an underdeveloped area in Australia and indeed, across the Asia-Pacific. Typically this segment of the market is stereotyped by tourism providers as having less disposable income. Unfortunately, this view has also affected government tourism marketing authorities, who on the whole have abrogated their responsibilities when it comes to the provision of equitable access to accessible tourism information and destination experiences. 
Until examples of good business practice are identified and promoted, the industry cannot be guided with certainty about the benefits in providing expanded accessible tourism products. Research projects like the one described here are a critical first step. Key measures or indicators were developed and operationalised, within the TBL framework, to evaluate the main components of accessible tourism businesses. Importantly, the insights provided by this investigation can promote the benefits of accessible tourism product provision to the tourism industry. Moreover, while the focus of this paper was one case study only, the broader research project itself provided scoping designed to point the way to additional research on expanding the key measures identified as important and informative. A number of gaps in our understanding of accessible tourism were also revealed; each is worthy of further exploration. These include: (1) greater analysis of accessible transport to and from tourism sites/accommodation, (2) due to the limited success in obtaining detailed financial data, more research is needed on this component which will require finding ways to satisfy participants' concerns about divulging this information, (3) a detailed analysis/breakdown of the international market currently attracted to accessible tourism in Australia, and (4) more defined sectoral analysis to define and ensure the benefits to each sector (transport, accommodation, experience/activities). 


\section{Acknowledgements:}

Photos courtesy (in web based version) of Greg Wilson, O’Carrollyns, G Douveas, B

Cameron and S Darcy. The research would like to acknowledge the research funding provided by the Sustainable Tourism Co-Operative Research Centre and the assistance of Dr Stephen Schweinsberg and Dr Matthew McDonald in preparing proofs of the paper.

\section{Legislation}

Disability Discrimination Act, 1992 [Comm.]

\section{References}

Altman, I. (1975). The environment and social behavior. Monterey, CA: Brooks-Cole Publishing.

Arnold, M., Heyne, L., \& Busser, J. (2005). Problem solving: Tools and techniques for the park and recreation administrator. Champaign, IL: Sagamore Publishing.

Aslaksen, F., Bergh, S., Bringa, O. R., \& Heggem, E. K. (1997). Universal design: Planning and design for all. Oslo, Norway: The Norwegian State Council on Disability.

Australian Bureau of Statistics (2004). Disability ageing and carers summary of findings, 2003 (Cat No. 4430.0). Canberra: Australian Bureau of Statistics.

Australian Hotels Association. (1998). Catering for guests with disabilities: Survey of AHA members. Canberra: Australian Hotels Association.

Balvanes, M., \& Caputi, P. (2001). Introduction to Quantitative Research Methods. London: Sage Publications.

Barron, L., \& Gauntlett, E. (2002). Housing and sustainable communities indicators project, Stage 1 Report - model of social sustainability. Perth, Australia: Western Australian Council of Social Services.

Buhalis, D., Michopoulou, E., Eichhorn, V., \& Miller, G. (2005). Accessibility market and stakeholder analysis - One-Stop-Shop for Accessible Tourism in Europe (OSSATE). Surrey, United Kingdom: University of Surrey.

Burnett, J. J., \& Bender-Baker, H. (2001). Assessing the travel-related behaviors of the mobility-disabled consumer. Journal of Travel Research, 40(1), 4-11.

Berg, B. L. (1989). Qualitative Research Methods for the Social Sciences. United States of America: Allyn and Bacon.

Cameron, B. (2000). Easy Access Australia: A Travel Guide to Australia (2nd ed.). Vic: Easy Access Australia Publishing Pty Ltd.

Center for Universal Design (n.d.). Universal design principles. Retrieved 2 May 2008, from, http://www.design.ncsu.edu:8120/cud.

City of Melbourne. (2006). Accessing Melbourne. Melbourne: City of Melbourne.

Commonwealth Department of Industry, Tourism and Resources (2003). White Paper: The medium to long-term strategy for tourism. Canberra: Australian Government Printing Service.

Commonwealth of Australia (2003). Intergenerational Report 2002-03 (Budget Paper No. 5). Canberra: Australian Government Printing Service. 
Creswell, J. W. (2003). Research Design: Qualitative, Quantitative, and Mixed Method Approaches (2nd ed. ed.). Thousand Oaks, California: Sage Publications.

Culyer, B. (1997). Making anything possible - Best practice in recreation services for people with a disability - draft report. Canberra: Australian Government Printing Service.

Darcy, S. (1998). Anxiety to access: tourism patterns and experiences of New South Wales people with a physical disability. Sydney: Tourism New South Wales.

Darcy, S. (2000). Tourism industry supply side perceptions of providing goods and services for people with disabilities. Sydney: New South Wales Ageing and Disability Department.

Darcy, S. (2001). People with physical disabilities and leisure. In I. Patterson \& T. Taylor (Eds.), Celebrating Inclusion and Diversity in Leisure (pp. 59-80). Melbourne: HM Leisure Planning Pty Ltd..

Darcy, S. (2002). Marginalised participation: Physical disability, high support needs and tourism. Journal of Hospitality and Tourism Management, 9(1), 61-72.

Darcy, S. (2003, 5-8 February). Disabling journeys: The tourism patterns of people with impairments in Australia. Paper in the proceedings of the Riding the Wave of Tourism and Hospitality Research, CAUTHE - Southern Cross University, Lismore. CD Rom.

Darcy, S. (2006). Setting a research agenda for accessible tourism. Gold Coast, Australia: Sustainable Tourism for Cooperative Research Centre.

Darcy, S. (2008, month Dec). Valuing accessible rooms: Understanding accessible tourism accommodation information preferences. Paper presented at Creating Inclusive Communities Conference - Association of Consultants in Access, Adelaide, Australia.

Darcy, S. (2010). Inherent complexity: Disability, accessible tourism and accommodation information preferences. Tourism Management, In press \& published online doi:10.1016/j.tourman.2009.08.010.

Darcy, S., \& Cameron, B. (2008). Accommodating Tourism: Hotel accommodation, accessible tourism and market principles - Evidence-based research. Independent Living: Official journal of Independent Living Centres Australia 24(4), 24-28.

Darcy, S., \& Dickson, T. (2009). A Whole-of-Life Approach to Tourism: The Case for Accessible Tourism Experiences. Journal of Hospitality and Tourism Management, 16(1), 32-44.

Darcy, S., \& Taylor, T. (2009). Disability citizenship: An Australian human rights analysis of the cultural industries. Leisure Studies, 28(4), 375-398.

Darcy, S., Cameron, B., Pegg, S. \& Packer, T. (2008). Developing business case studies for accessible tourism. Gold Coast, Australia: Sustainable Tourism for Cooperative Research Centre.

Deafness Forum, \& HMAA. (2005). Accommodation Industry Voluntary Code of Practice for the Provision of Facilities for the Deaf and Hearing Impaired Sydney: HMAA.

Department for Works and Pensions (2008). Working in the tourism sector - Questions for small to medium-sized businesses. Retrieved 1 April 2008, from, http://www.dwp.gov.uk/employers/dda/case tourism.asp

Dey, I. (1993). Qualitative Data Analysis: A User-Friendly Guide for Social Scientists. New York: Routledge.

Dredge, D. \& Jenkins, J. (2003). Destination place identity and regional tourism policy. Tourism Geographies, 5(4), 383-407.

Dwyer, L. (2005). Trends underpinning global tourism in the coming decade. In Theobald, W. (Ed.) Global tourism (pp. 529-545). Burlington, MA: Butterworth Heinemann.

Dwyer, L., \& Darcy, S. (2008). Chapter 4 - Economic contribution of disability to tourism in Australia. In S. Darcy, B. Cameron, L. Dwyer, T. Taylor, E. Wong \& A. Thomson 
(Eds.), Technical Report 90040: Visitor accessibility in urban centres (pp. 15-21).

Gold Coast: Sustainable Tourism Cooperative Research Centre.

Eichhorn, V., \& Buhalis, D. (2007). The accessibility requiring market in Europe: Socially and economically important. e-Review of Tourism Research, 5(2), 34-36.

Eichhorn, V., Miller, G., Michopoulou, E., \& Buhalis, D. (2008). Enabling access to tourism through information schemes? Annals of Tourism Research, 35(1), 189-210.

Elkington, J. (1997). Cannibals with forks: The triple bottom line in 21st century businesses. Oxford, UK: Capstone.

English Tourism Council. (2000). People with Disabilities and Holiday Taking. London: English Tourist Council.

ESCAP. (2008). Disability at a glance: a Profile of 28 Countries and Areas in Asia and the Pacific. United Nations - Economic and Social Commission for Asia and the Pacific, Vietnam. from http://www.unescap.org/esid/psis/disability

Fujiura, G. L. \& Rutkowskikmitta, V. (2001). Counting disability. In Albrecht, G. L., Seelman, K. D. \& Bury, M. (Eds.) Handbook of disability studies (pp. 69-96). Thousand Oaks, CA: Sage Publications.

Gilkison, B. (1999). Accounting for a clean green environment: Obligations and opportunities for New Zealand businesses and their accountants. Nelson, NZ: Anchor Press.

HarrisInteractive Market Research. (2005). Research among adults with disabilities - travel and hospitality. Chicago: Open Doors Organization.

Henderson, K., \& Bialeschki, D. (2002). Evaluating Leisure Services: Making Enlightened Decisions (2nd ed.). State College, PA: Venture Publishing.

Holbeche, L. (2006). Understanding change. Theory, implementation and success. Boston, MA: Butterworth-Heinemann.

Hutchison, P. (1997, 10-12 October). Citizenship - Setting the Scene (Keynote Address). Paper presented at the Citizenship...beyond Disability Conference, Brisbane.

Hutchison, P., \& McGill, J. (1998). Leisure, integration and community (2nd ed.). Toronto: Leisurability Publications.

Johannisson, B. \& Nilsson, A. (1989). Community entrepreneurs: Networking for local development. Entrepreneurship \& Regional Development, 1(1), 3-19.

Johannisson, B. (1990). Community entrepreneurship-cases and conceptualization. Entrepreneurship \& Regional Development, 2(1), 71-88

Keroul. (2001). A Growth Market: Behaviours of Tourists with Restricted Physical Abilities in Canada. Quebec: Keroul.

Kotter, J. P. (1998). Leading change: Why transformation efforts fail. Harvard Business Review, 2, 1-21.

Leiper, N., Stear, L., Hing, N., \& Firth, T. (2008). Partial industrialisation in tourism: A new model. Current Issues in Tourism, 11(3), 207 - 235.

Lyons, M. (2001). Third sector: The contribution of non-profit and cooperative enterprise in Australia. Sydney: Allen \& Unwin.

MacLagan, P. (2003). The change-capable organization. Training \& Development, 57(1), 5058.

Mason, J. (2002). Qualitative interviewing: Asking, listening and interpreting. In T. May (Ed.), Qualitative Research in Action. London: Sage Publications.

Meekosha, H., \& Dowse, L. (1997). Enabling Citizenship: Gender, disability and citizenship in Australia. Feminist Review, 57(Autumn), 49-72.

Miller, G. A., \& Kirk, E. (2002). The Disability Discrimination Act: Time for the stick? Journal of Sustainable Tourism, 10(1), 82-88. 
Moon, S., Hart, D., Komissar, C., and Freidlander, R. (1995). Making sports and recreation activities accessible: Assistive technology and other accommodations. In K. Flippo, K. Inge, \& J. Barchus (Eds.), Assistive technology: A resource for school, work and community (pp. 187-198). Baltimore, MD: Paul H. Brookes.

Morse, J. M. (1991). Approaches to qualitative-quantitative methodological triangulation. Nursing Research, 40, 120-123.

Murray, M., \& Sproats, J. (1990). The disabled traveller: Tourism and disability in Australia. Journal of Tourism Studies, 1(1), 9-14.

Newsome, D., Moore, S. A., \& Dowling, R. K. (2002). Natural area tourism: Ecology, impacts and management. Clevedon, UK: Channel View Publications.

Office of National Tourism (1998). The tourism challenge: Access for all. Canberra: Australian Government Printing Service.

Okello, M. M. (2005). A survey of tourist expectations and economic potential for a proposed wildlife sanctuary in a Maasai Group Ranch near Amboseli, Kenya. Journal of Sustainable Tourism, 13(6), 566-589.

O'Neill, M., \& Ali Knight, J. (2000). Disability tourism dollars in Western Australia hotels. FIU Hospitality Review, 18(2), 72-88.

Ostroff, E. (2001). Universal design: The new paradigm. In W. Preiser \& E. Ostroff (Eds.), Universal design handbook (pp. 3-12). New York: McGraw Hill.

Packer, T., Small, J., \& Darcy, S. (2008). Technical Report 90044: Tourist Experiences of Individuals with Vision Impairment STCRC Technical Report Available from http://www.crctourism.com.au/default.aspxg

Patton, M. Q. (2002). Qualitative research and evaluation methods (3rd ed. ed.). Thousand Oaks, California: Sage Publications.

Pegg, S., \& Stumbo, N. (2008) Creating opportunities and ensuring access to desirable heritage and cultural tourist services and leisure experiences. In B. Prideaux, D. Timothy \& K. Chon (Eds.) Cultural and heritage tourism in Asia and the Pacific (pp. 250-256). New York: Routledge.

Preiser, W. F. E. \& Ostroff, E. (2001). Universal design handbook. New York: McGraw-Hill.

Rains, S. (2004, December). Universal design and the international travel and hospitality industry. Paper presented at Designing for the 21st Century III Conference An International Conference on Universal Design, Rio de Janeiro, Brazil.

Savitz, A. W., \& Weber, K. (2006). The triple bottom line: How today's best-run companies are achieving economic, social and environmental success - and how you can too. San Francisco, CA: Jossey Bass.

Stake, R. E. (1994). Case Studies. In N. K. Denzin \& Y. S. Lincoln (Eds.), Handbook of Qualitative Research (pp. 236-245). Thousand Oaks, CA: Sage.

Standards Australia. (2001). AS 1428.1 Design for access and mobility - General requirements for access - New building work. Homebush, NSW: Standards Australia.

Steinfeld, E. \& Shea, S. M. (2001). Fair housing: Toward universal design in multifamily housing. In W.F.E. Preiser \& E. Ostroff (Eds.) Universal design handbook (pp. 35.135.13). New York: McGraw-Hill.

Storer, C. E. \& Frost, F. M. (2002). Triple bottom line reporting: It's relevance and application to agricultural production and marketing. In Batt, P. J. (Ed.) From farm to fork: Linking producers to consumers through value chains. Proceedings, Muresk 75th Anniversary Conference, 3-4 October. Perth, Australia.

Tourism Australia (2005). Markets - Australian experiences - niche experiences. Retrieved 20 May 2008, from, http://www.tourism.australia.com/Markets.asp?lang=EN\&sub=0338

Victorino, L., Verma, R., \& Wardell, D. (2008). Service scripting: A customer’s perspective 
of quality and performance. Cornell Hospitality Report, 8(20), 4-13.

Villamanta Publishing. (1997). Right of Access - A Guide to Developing Action Plans and Improving Access for People with Disabilities. Melbourne: Villamanta Publishing.

Walsh, C. J. (2004, December). Rio de Janeiro declaration on sustainable social development, disability \& ageing. Paper presented at Designing for the 21st Century III - An International Conference on Universal Design, Rio de Janeiro, Brazil.

Woodside, A. G., \& Etzel, M. J. (1980). Impact of physical and mental handicaps on vacation travel behaviour. Journal of Travel Research, 18(3), 9-11.

Worboys, G., Lockwood, M., \& De Lacy, T. (2005). Protected area management: Principles and practice (2nd ed.). Oxford, UK: Oxford University Press.

World Health Organization (2007). Global age-friendly cities guide. Retrieved 19 May 2008, from, http://www.who.int/ageing/age friendly_cities/en/index.html

Yin, R. K. (2003). Case Study Research: Designs and Methods. Thousand Oaks, CA: Sage Publications.

Zikmund, W. (2003). Business Research Methods (7th ed ed.). South Western: Thomson. 